\title{
The impact of Champagne wine consumption on vascular and cognitive functions
}

Giulia Corona ${ }^{\mathrm{a}}$, Jeremy P.E. Spencera and David Vauzour ${ }^{\mathrm{b} *}$

aMolecular Nutrition Group, School of Chemistry, Food and Pharmacy, University of Reading, Reading RG6 6AP, UK; bNorwich Medical School, Faculty of Medicine and Health Sciences, University of East Anglia, Norwich NR4 7TJ.

Running title: Health effects of Champagne wine

* Correspondence to: Dr David Vauzour, Norwich Medical School, Faculty of Medicine and Health Sciences, University of East Anglia, Norwich NR4 7TJ. Email; D.Vauzour@uea.ac.uk; Tel: +44 (0) 1603 591732; Fax: +44 (0)1603 593752

Keywords: Champagne wine, polyphenols, phenolic acids, CVD, memory, cognition, aging. 


\section{Abstract}

Epidemiological evidence suggests an inverse correlation between wine consumption and the incidence of cardiovascular and neurodegenerative disorders. Although white wines are generally low in polyphenol content as compared to red wines, Champagne wine has been shown to contain relatively high amounts of phenolic acids that may exert protective cellular actions in vivo. Recent evidence suggest that Champagne phenolic acids may express their beneficial properties through their interaction with cellular signaling pathways and related machinery that mediate cell function under both normal and pathological conditions. In this review we aim to provide an overview of the role that Champagne consumption plays in maintaining cardiovascular health and cognitive function. We discuss epidemiological data, human intervention study findings, as well as animal and in vitro studies in support of these actions and we consider how their biological mechanisms at the cellular level may underpin their physiological effects. Together, these data indicate that polyphenols present in Champagne may hold cardioprotective and neuroprotective potential in delaying the onset of degenerative disorders. 


\section{Introduction}

Despite the well-established harmful effects of heavy alcohol intake [1], epidemiological studies have reported that a low to moderate intake of wine (1-2 glasses per day), may reduce the risk of cardiovascular disease and cognitive impairment [2-5]. In particular, a J-shaped relationship between the amount of wine consumed and the risk of cardiovascular disease, such as hypertension, has been previously described [6-7]. These observations have been further substantiated by series of large scale, cross sectional and prospective studies, which have almost universally demonstrated a strong inverse correlation between wine consumption and the risk of cardiovascular disease [8]. In addition, incidence data from the so-called Personnes Agees Quid [2] study demonstrated that people drinking three to four glasses of wine per day had an $80 \%$ decreased incidence of dementia and Alzheimer's disease three years later, compared to those who drank less or did not drink at all [4]. Such protection is believed to be in large part attributable to the intake of specific polyphenols present in great quantity in wine. In particular, flavonoids, a subclass of polyphenols, have been ascribed to exert anti-inflammatory properties [9] and to modulate signalling pathways that regulate nitric oxide production [10] and neuronal survival [11]. As such, there is a great interest in the potential of regular and moderate wine consumption to counteract vascular ageing and to delay the onset of neurological disorders, such as Alzheimer's disease and dementia [12-14].

Although red wines contain high levels of flavonoids and other phenolics relative to white wines [15], Champagne wine is relatively rich in phenolic compounds (Table 1) such as hydroxybenzoic acids, hydroxycinnamic acids (and their tartaric derivative esters), phenolic alcohols and phenolic aldehydes [16-17]. The phenolic composition varies with a wide range of factors, including species, variety, season, growing conditions, and processing practices [18]. The increased levels of phenolic compounds in Champagne wine compared to other white wines, derive predominantly from the two red grapes, Pinot Noir and Pinot Meunier, which are used in its production along with the white grape Chardonnay [19]. Moderate Champagne consumption has been shown to exert a number of effects in vivo, including modulation of peripheral serotonin and dopamine release [20] and to increase plasma vitamin $A$ concentration [21]. In addition, Champagne polyphenols have been shown to protect primary neuronal cells against peroxynitrite-induced injury [16], a physiologically relevant oxidizing species which has been implicated in vascular wall pathology [22] and neurodegeneration [23]. As such, Champagne wine 
can deliver significant quantities of phenolic compounds capable of mediating changes in cardiovascular health and cognitive performance. In this manuscript, we will review the effects of Champagne wine on vascular health and cognitive functions and we will briefly describe their intracellular targets underlying their protective effects.

\section{Champagne wine and vascular health}

Cardiovascular disease (CVD), in particular coronary heart disease and stroke, is a major cause of mortality in the Western countries. Epidemiological and human intervention studies have suggested that a daily and moderate consumption of red or white wine is associated with a lower incidence of CVD [24]. Many of the effects of red wine are compatible with the action of wine-derived polyphenols on endothelium-derived nitric oxide (NO*) production [25], whilst white wine effects may result from the synergistic actions of polyphenols and other phenolic constituents on LDL oxidation and platelet function [26]. Moderate red wine intake has also been associated with a reduced coronary artery disease mortality [27-28], through its ability to improve endothelial function [29], to induce an acute increase in endothelium-dependent flow-mediated dilatation [30-31] and to inhibit endothelin-1 synthesis [32-33].

In particular, these biological effects have been linked to flavonoids, hydroxycinnamates and phenolic acids present in great concentration in these wines [34]. Following consumption, nanomolar quantities of flavonoids and other polyphenols enter the circulation [34-35] where they may act to improve nitric oxide bioavailability and/or inhibit endothelin-1 (ET-1) [36-37]. In support of this statement, the cardioprotective effects of white wines have been reported [38-39], although they contain lower concentration of flavonoids and induce reduced vascular effects when compared to red wines [40-41]. Moderate Champagne wine consumption has also been shown to exert a number of effects in vivo, effecting peripheral serotonin and dopamine release [20] and increasing plasma vitamin A concentration [21]. In addition, Champagne wine polyphenols have also been shown to protect cells against injury induced by peroxynitrite [16], a physiologically relevant oxidizing species which has been implicated in vascular wall pathology $[22,42]$.

Recently we reported that moderate consumption of Champagne wine, but not a control matched for alcohol, carbohydrate and fruit-derived acid content, improved microvascular blood flow and vascular responsiveness in healthy volunteers [43]. By using Laser Doppler and iontophoresis (LDI), we 
demonstrated that absorbed hydroxycinnamates and their metabolites influenced vascular function (Figure 1) by inducing an acute change in endothelium-independent vasodilatation at 4, 6 and $8 \mathrm{~h}$ post consumption, whilst the control did not induce any changes in vascular reactivity [43]. These effects were accompanied by an acute decrease in the concentration of matrix metalloproteinase MMP-9 and a significant decrease in plasma levels of oxidising species. These biological effects were paralleled by a urinary excretion of phenolic metabolites. In particular, the mean total excretion of hippuric acid, protocatechuic acid and isoferulic acid were all significantly greater following the Champagne wine intervention compared to control intervention, suggesting that they may be responsible for the observed vascular activity [43]. Together, these data suggest that consumption of Champagne wine phenolic acids may enhance microvascular blood flow for a sustained period of time after consumption, through the maintenance of local nitric oxide levels. Altogether, these results suggest that Champagne wine has some short-term effects on the blood vessels that are not solely caused by its alcohol content. However, it would be premature to extrapolate the "proxy" outcomes of blood vessel dilation to clinical outcomes, such as heart disease.

\section{Champagne wine and cognitive function}

Polyphenols-rich foods/beverages have received much attention with regards to their neuroprotective effects [44], including a potential to protect neurons against neurotoxin-induced injury [45-46], to suppress neuroinflammation [47], and to promote memory and learning [48-51]. Despite the wellestablished harmful effects of heavy alcohol intake [1], epidemiological data suggest that moderate wine consumption may reduce the incidence of age-related dementia, including Alzheimer's disease [4, 52-53]. As such, there is an interest in the potential of regular, moderate wine consumption to counteract normal brain ageing and to improve memory and learning, through its potential to deliver relatively high amounts of flavonoids and phenolic acids [12-13]. Animal data support these findings and indicate that moderate consumption of red wine attenuates $A \beta$-neuropathology in a mouse model of Alzheimer's disease [54]. In a recent rodent study we reported that Champagne wine is also capable of enhancing spatial working memory (without altering motor performance) in aged animals [55]. In contrast, moderate alcohol intake failed to induce spatial memory changes. These observations are in agreement with those observed following long-term red wine intake in a similar model of hippocampal- 
dependent spatial memory [56]. The effects of Champagne on spatial memory (Figure 2) were paralleled by a number of changes in hippocampal and cortical protein expression, which may explain performance on spatial memory tasks. Targeted protein arrays indicated that Champagne induced the differential expression of a number of hippocampal and cortical proteins involved in signal transduction, neuroplasticity, apoptosis and cell cycle regulation [55]. Most notably, we observed the differential modulation of a range of proteins, such as brain-derived neurotrophic factor (BDNF), CAMP response element-binding protein (CREB), p38, dystrophin, 2',3'-Cyclic-nucleotide 3'-phosphodiesterase (CNPase), mammalian target of rapamycin (mTOR), B-cell lymphoma2-extra large protein (Bcl-xL) in response to Champagne supplementation compared to the control drink, and the modulation of mTOR, $\mathrm{Bcl}-\mathrm{xL}$ and $\mathrm{CREB}$ in response to alcohol supplementation [55].

CNPase is a myelin-associated enzyme that constitutes around $4 \%$ of total CNS myelin protein, and is thought to undergo significant age-associated changes [57], and is reduced in Alzheimer's disease and Down's syndrome patients [58]. Furthermore, Champagne-induced hippocampal increases in the cytoskeletal associated protein, dystrophin, may be beneficial as a lack of this protein in the hippocampus has been associated with impaired cognitive function [59], spatial memory [60] and longterm potentiation [61]. Indeed, patients lacking dystrophin in the hippocampus and neocortex (due to mutation in the dystrophin gene) display a range of cognitive deficits [62]. Intervention with the phenolic rich Champagne also led to the increased expression of a range of 'other' cytoskeletal proteins, including plakoglobin ( $\mathrm{Y}$-catenin), spectrin, calponin, cytokeratin pep4 and pep19, myosin Va and Focal Adhesion Kinase [55]. Such proteins facilitate complex neuronal network formation in the brain and operate with neuronal membrane proteins (e.g., ion channels, scaffolding proteins, and adaptor proteins) at sites of synaptic contacts to regulate synaptogenesis and coordinate synaptic strength [6364]. Our data therefore suggest that smaller phenolics such as gallic acid, protocatechuic acid, tyrosol, caftaric acid and caffeic acid, in addition to flavonoids, are capable of exerting improvements in spatial memory via the modulation in hippocampal signalling and protein expression.

\section{Mechanisms of action}

Champagne wine consumption has been observed to improve acute vascular function [43], in a similar manner to that of red wine [65-66]. Champagne wine and specifically its phenolic metabolites may affect 
vascular function by improving local nitric oxide bioavailability by two potential mechanisms. Firstly, they may increase the local half-life of NO via reaction with reactive oxygen species, such as superoxide [67]. Secondly, phenolic metabolites, such as those excreted post champagne consumption, may mimic NADPH oxidase inhibitors [68], such as apocynin thereby reducing the cellular production of superoxide and increasing the half-life of $\mathrm{NO}^{\circ}$, without any change in the rate of $\mathrm{NO}$ synthesis [69]. Furthermore, tyrosol, caffeic acid, and gallic acid, phenolic compounds found at relatively high concentrations in Champagne, have been shown to potently inhibit peroxynitrite-induced cellular injury at physiologically relevant concentrations $(0.1$ to $10 \mu \mathrm{M})[16]$, whilst nanomolar levels of tyrosol, caffeic acid and p-coumaric acid protect cortical neurons against 5-S-cysteinyl-dopamine induced injury [70]. Indeed, the level of protection induced by these phenolics was equal to, if not greater than, that observed for similar concentration of the flavonoids, (+)-catechin, (-)-epicatechin and quercetin [70]. The hydroxycinnamate, caffeic acid, has also been shown to be neuroprotective, counteracting inflammatory injury induced by 1 -methyl-4-phenyl-1,2,3,6-tetrahydropyridine (MPTP) by decreasing the production of a number of inflammatory cytokines, down-regulating the expression of iNOS, COX-2 and glial fibrillary acidic protein and lowering the production of $\mathrm{NO}$ and $\mathrm{PGE}_{2}$ [71]. In addition, caffeic acid phenethyl ester may protect cerebellar granule neurons against glutamate-induced neuronal death via inhibition of p38 phosphorylation and caspase-3 activation [72] and significantly prevents hypoxic-ischaemic-induced neonatal rat brain damage in the cortex, hippocampus and thalamus [73]. Indeed, for any polyphenol to exert direct neuroprotective actions they must also undergo permeation of the blood brain barrier (BBB), something that has been reported for both flavonoids and hydroxycinnamates [74]. However, whilst the ability of flavonoids to cross the BBB is believed to be dependent on lipophilicity, small phenolics are thought to transverse the BBB via amino acid transporters, such as has been reported for 4-ethylcatechol [75]. Furthermore, caffeic acid shares structural similarities with L-DOPA and, as such, may undergo BBB transport via catecholamine transporter systems.

It is well reported that flavonoids may exert cellular action by interacting with the PI 3-kinase, Akt/PKB and MAP kinase signalling pathways [11]. Smaller phenolics, such as caffeic acid or tyrosol, may also participate in cellular interactions of this nature [76], or may directly react with toxic intermediates, as has been observed for $p$-coumaric acid [77]. All together, these processes act to maintain the number 
and quality of synaptic connections in the brain, a factor known to be essential for efficient long term potentiation (LTP), synaptic plasticity and ultimately the efficient working of memory.

\section{Conclusions}

The development of cardiovascular and cognitive impairment is a complex process that begins even in the absence of a symptomatic disease [78]. Human clinical trials and animal studies have identified polyphenol-rich foods and beverages as being capable of delaying the onset of age-related vascular and cognitive impairment [44, 79-83]. Polyphenols present in such foods have been postulated to evoke protection through the actions of absorbed flavonoids and their metabolites at the cellular level, enhancing existing endothelial and neuronal function and/or stimulating cell regeneration $[44,79,83-$ 84]. Although antioxidant mechanisms cannot be excluded [85], recent data sets suggest that such effects are mediated by their ability to modulate endothelial and neuronal signalling [86-87], to stimulate neurotransmitter release [88], to increase vascular blood flow [89] and even to stimulate hippocampal neurogenesis [90]. We previously provided evidence that moderate Champagne wine consumption induces improvements in vascular health and cognitive function, dependent on the potential of Champagne phenolic compounds to modulate endothelial and neuronal cell signalling [70,91], and to enhance blood flow in vivo. Altogether, these results suggest that Champagne wine consumption holds a potential to limit neurodegeneration and is capable of vascular improvements $[43,55,92]$. However, the pharmacological potential of these natural compounds still remains to be translated in humans in clinical conditions. The challenge ahead therefore, is to proceed cautiously until rigorous randomized controlled clinical trials have been undertaken to determine whether Champagne wine polyphenols and/or their in vivo metabolites have efficacy in patients suffering from cardiovascular episodes or from loss of neuronal function.

\section{References}

[1] Hvidtfeldt UA, Frederiksen ME, Thygesen LC, Kamper-Jorgensen M, Becker U, Gronbaek M. Incidence of cardiovascular and cerebrovascular disease in Danish men and women with a prolonged heavy alcohol intake. Alcohol Clin Exp Res. 2008;32(11):1920-4. 
[2] Lemeshow S, Letenneur L, Dartigues JF, Lafont S, Orgogozo JM, Commenges D. Illustration of analysis taking into account complex survey considerations: the association between wine consumption and dementia in the PAQUID study. Personnes Ages Quid. Am J Epidemiol. 1998;148(3):298-306 .

[3] Letenneur L. Risk of dementia and alcohol and wine consumption: a review of recent results. Biol Res. 2004;37(2):189-93.

[4] Orgogozo JM, Dartigues JF, Lafont S, Letenneur L, Commenges D, Salamon R, Renaud S, Breteler MB. Wine consumption and dementia in the elderly: a prospective community study in the Bordeaux area. Rev Neurol (Paris). 1997;153(3):185-92.

[5] Krenz M, Korthuis RJ. Moderate ethanol ingestion and cardiovascular protection: from epidemiologic associations to cellular mechanisms. J Mol Cell Cardiol. 2012;52(1):93-104.

[6] Klatsky AL, Friedman GD, Siegelaub AB. Alcohol consumption before myocardial infarction. Results from the Kaiser-Permanente epidemiologic study of myocardial infarction. Ann Intern Med. 1974;81(3):294-301.

[7] St Leger AS, Cochrane AL, Moore F. Ischaemic heart-disease and wine. Lancet. 1979;1(8129):1294.

[8] de Gaetano G, Di Castelnuovo A, Rotondo S, lacoviello L, Donati MB. A meta-analysis of studies on wine and beer and cardiovascular disease. Pathophysiol Haemost Thromb. 2002;32(5-6):353-5. [9] Rice-Evans CA, Miller NJ. Antioxidant activities of flavonoids as bioactive components of food. Biochemical Society Transactions. 1996;24(3):790-5.

[10] Bastianetto S. Red wine consumption and brain aging. Nutrition. 2002;18(5):432-3.

[11] Schroeter H, Boyd C, Spencer JP, Williams RJ, Cadenas E, Rice-Evans C. MAPK signaling in neurodegeneration: influences of flavonoids and of nitric oxide. Neurobiology of Aging. 2002;23(5):861-80.

[12] Corder R. Red wine, chocolate and vascular health: developing the evidence base. Heart. 2008;94(7):821-3.

[13] Chan SL, Tabellion A, Bagrel D, Perrin-Sarrado C, Capdeville-Atkinson C, Atkinson J. Impact of chronic treatment with red wine polyphenols (RWP) on cerebral arterioles in the spontaneous hypertensive rat. J Cardiovasc Pharmacol. 2008;51(3):304-10. 
[14] Commenges D, Scotet V, Renaud S, Jacqmin-Gadda H, Barberger-Gateau P, Dartigues JF. Intake of flavonoids and risk of dementia. Eur J Epidemiol. 2000;16(4):357-63.

[15] Manach C, Scalbert A, Morand C, Remesy C, Jimenez L. Polyphenols: food sources and bioavailability. The American journal of clinical nutrition. 2004;79(5):727-47.

[16] Vauzour D, Vafeiadou K, Corona G, Pollard SE, Tzounis X, Spencer JP. Champagne wine polyphenols protect primary cortical neurons against peroxynitrite-induced injury. J Agric Food Chem. 2007;55(8):2854-60.

[17] Chamkha M, Cathala B, Cheynier V, Douillard R. Phenolic composition of champagnes from Chardonnay and Pinot Noir vintages. J Agric Food Chem. 2003;51(10):3179-84.

[18] Jackson DI, Lombard PB. Environmental and Management-Practices Affecting Grape Composition and Wine Quality - a Review. Am J Enol Viticult. 1993;44(4):409-30.

[19] Constant J. Alcohol, ischemic heart disease, and the French paradox. Coron Artery Dis. $1997 ; 8(10): 645-9$.

[20] Boyer JC, Bancel E, Fabbro Perray P, Pouderoux P, Balmes JL, Bali JP. Effect of Champagne compared to still white wine on peripheral neurotransmitter concentrations. International Journal for Vitamin and Nutrition Research. 2004;74(5):264-71.

[21] Cartron E, Fouret G, Carbonneau MA, Lauret C, Michel F, Monnier L, Descomps B, Léger CL. Red-wine beneficial long-term effect on lipids but not on antioxidant characteristics in plasma in a study comparing three types of wine - Description of two O-methylated derivatives of gallic acid in humans. Free Radical Research. 2003;37(9):1021-35.

[22] van der Loo B, Labugger R, Skepper JN, Bachschmid M, Kilo J, Powell JM, Palacios-Callender M, Erusalimsky JD, Quaschning T, Malinski T, Gygi D, Ullrich V, Luscher TF. Enhanced peroxynitrite formation is associated with vascular aging. Journal of Experimental Medicine. 2000;192(12):1731-44. [23] Szabo C, Ischiropoulos H, Radi R. Peroxynitrite: biochemistry, pathophysiology and development of therapeutics. Nature Reviews Drug Discovery. 2007;6(8):662-80.

[24] Renaud S, de Lorgeril M. Wine, alcohol, platelets, and the French paradox for coronary heart disease. Lancet. 1992;339(8808):1523-6.

[25] Flesch M, Schwarz A, Bohm M. Effects of red and white wine on endothelium-dependent vasorelaxation of rat aorta and human coronary arteries. American Journal of Physiology. 1998;275(4 Pt 2):H1183-90. 
[26] Pignatelli P, Ghiselli A, Buchetti B, Carnevale R, Natella F, Germano G, Fimognari F, Di Santo S, Lenti L, Violi F. Polyphenols synergistically inhibit oxidative stress in subjects given red and white wine. Atherosclerosis. 2006;188(1):77-83.

[27] Gronbaek M, Becker U, Johansen D, Gottschau A, Schnohr P, Hein HO, Jensen G, Sorensen TI. Type of alcohol consumed and mortality from all causes, coronary heart disease, and cancer. Ann Intern Med. 2000;133(6):411-9.

[28] Klatsky AL, Friedman GD, Armstrong MA, Kipp H. Wine, liquor, beer, and mortality. Am J Epidemiol. 2003;158(6):585-95.

[29] Szmitko PE, Verma S. Antiatherogenic potential of red wine: clinician update. Am J Physiol Heart Circ Physiol. 2005;288(5):H2023-30.

[30] Agewall S, Wright S, Doughty RN, Whalley GA, Duxbury M, Sharpe N. Does a glass of red wine improve endothelial function? Eur Heart J. 2000;21(1):74-8.

[31] Hashimoto M, Kim S, Eto M, lijima K, Ako J, Yoshizumi M, Akishita M, Kondo K, Itakura H, Hosoda K, Toba K, Ouchi Y. Effect of acute intake of red wine on flow-mediated vasodilatation of the brachial artery. Am J Cardiol. 2001;88(12):1457-60, A9.

[32] Fitzpatrick DF, Hirschfield SL, Coffey RG. Endothelium-dependent vasorelaxing activity of wine and other grape products. Am J Physiol. 1993;265(2 Pt 2):H774-8.

[33] Corder R, Douthwaite JA, Lees DM, Khan NQ, Viseu Dos Santos AC, Wood EG, Carrier MJ. Endothelin-1 synthesis reduced by red wine. Nature. 2001;414(6866):863-4.

[34] Scalbert A, Williamson G. Dietary intake and bioavailability of polyphenols. J Nutr. 2000;130(8S Suppl):2073S-85S.

[35] Spencer JP, Abd El Mohsen MM, Minihane AM, Mathers JC. Biomarkers of the intake of dietary polyphenols: strengths, limitations and application in nutrition research. Br J Nutr. 2008;99(1):12-22. [36] Loke WM, Hodgson JM, Proudfoot JM, McKinley AJ, Puddey IB, Croft KD. Pure dietary flavonoids quercetin and (-)-epicatechin augment nitric oxide products and reduce endothelin-1 acutely in healthy men. The American journal of clinical nutrition. 2008;88(4):1018-25. [37] Stoclet JC, Chataigneau T, Ndiaye M, Oak MH, El Bedoui J, Chataigneau M, Schini-Kerth VB. Vascular protection by dietary polyphenols. Eur J Pharmacol. 2004;500(1-3):299-313. [38] Cui J, Tosaki A, Cordis GA, Bertelli AA, Bertelli A, Maulik N, Das DK. Cardioprotective abilities of white wine. Ann N Y Acad Sci. 2002;957:308-16. 
[39] Dudley JI, Lekli I, Mukherjee S, Das M, Bertelli AA, Das DK. Does white wine qualify for French paradox? Comparison of the cardioprotective effects of red and white wines and their constituents: resveratrol, tyrosol, and hydroxytyrosol. J Agric Food Chem. 2008;56(20):9362-73.

[40] Shimada K, Watanabe H, Hosoda K, Takeuchi K, Yoshikawa J. Effect of red wine on coronary flow-velocity reserve. Lancet. 1999;354(9183):1002.

[41] van Velden DP, Mansvelt EP, Fourie E, Rossouw M, Marais AD. The cardioprotective effect of wine on human blood chemistry. Ann N Y Acad Sci. 2002;957:337-40.

[42] Xu S, Ying J, Jiang B, Guo W, Adachi T, Sharov V, Lazar H, Menzoian J, Knyushko TV, Bigelow D, Schoneich C, Cohen RA. Detection of sequence-specific tyrosine nitration of manganese SOD and SERCA in cardiovascular disease and aging. Am J Physiol Heart Circ Physiol. 2006;290(6):H2220-7. [43] Vauzour D, Houseman EJ, George TW, Corona G, Garnotel R, Jackson KG, Sellier C, Gillery P, Kennedy OB, Lovegrove JA, Spencer JP. Moderate Champagne consumption promotes an acute improvement in acute endothelial-independent vascular function in healthy human volunteers. $\mathrm{Br} \mathrm{J}$ Nutr. 2010;103(8):1168-78.

[44] Spencer JP. The impact of flavonoids on memory: physiological and molecular considerations. Chem Soc Rev. 2009;38(4):1152-61.

[45] Rainey-Smith S, Schroetke LW, Bahia P, Fahmi A, Skilton R, Spencer JP, Rice-Evans C, Rattray M, Williams RJ. Neuroprotective effects of hesperetin in mouse primary neurones are independent of CREB activation. Neurosci Lett. 2008;438(1):29-33.

[46] Vauzour D, Ravaioli G, Vafeiadou K, Rodriguez-Mateos A, Angeloni C, Spencer JP. Peroxynitrite induced formation of the neurotoxins 5-S-cysteinyl-dopamine and DHBT-1: implications for Parkinson's disease and protection by polyphenols. Arch Biochem Biophys. 2008;476(2):145-51. [47] Vafeiadou K, Vauzour D, Spencer JP. Neuroinflammation and its modulation by flavonoids. Endocr Metab Immune Disord Drug Targets. 2007;7(3):211-24.

[48] Shukitt-Hale B, Cheng V, Joseph JA. Effects of blackberries on motor and cognitive function in aged rats. Nutr Neurosci. 2009;12(3):135-40.

[49] Liu P, Kemper LJ, Wang J, Zahs KR, Ashe KH, Pasinetti GM. Grape seed polyphenolic extract specifically decreases abeta*56 in the brains of Tg2576 mice. J Alzheimers Dis. 2011;26(4):657-66. 
[50] Rendeiro C, Vauzour D, Kean RJ, Butler LT, Rattray M, Spencer JP, Williams CM. Blueberry supplementation induces spatial memory improvements and region-specific regulation of hippocampal BDNF mRNA expression in young rats. Psychopharmacology (Berl). 2012.

[51] Valls-Pedret C, Lamuela-Raventos RM, Medina-Remon A, Quintana M, Corella D, Pinto X, Martinez-Gonzalez MA, Estruch R, Ros E. Polyphenol-rich foods in the Mediterranean diet are associated with better cognitive function in elderly subjects at high cardiovascular risk. J Alzheimers Dis. 2012;29(4):773-82.

[52] Panza F, Capurso C, D'Introno A, Colacicco AM, Frisardi V, Lorusso M, Santamato A, Seripa D, Pilotto A, Scafato E, Vendemiale G, Capurso A, Solfrizzi V. Alcohol drinking, cognitive functions in older age, predementia, and dementia syndromes. J Alzheimers Dis. 2009;17(1):7-31.

[53] Weyerer S, Schaufele M, Wiese B, Maier W, Tebarth F, van den Bussche H, Pentzek M, Bickel H, Luppa M, Riedel-Heller SG. Current alcohol consumption and its relationship to incident dementia: results from a 3-year follow-up study among primary care attenders aged 75 years and older. Age Ageing. 2011;40(4):456-63.

[54] Wang J, Ho L, Zhao Z, Seror I, Humala N, Dickstein DL, Thiyagarajan M, Percival SS, Talcott ST, Pasinetti GM. Moderate consumption of Cabernet Sauvignon attenuates Abeta neuropathology in a mouse model of Alzheimer's disease. FASEB J. 2006;20(13):2313-20.

[55] Corona G, Vauzour D, Hercelin J, Williams CM, Spencer JP. Phenolic acid intake, delivered via moderate champagne wine consumption, improves spatial working memory via the modulation of hippocampal and cortical protein expression/activation. Antioxidants \& redox signaling. 2013;19(14):1676-89.

[56] Assuncao M, Santos-Marques MJ, de Freitas V, Carvalho F, Andrade JP, Lukoyanov NV, PaulaBarbosa MM. Red wine antioxidants protect hippocampal neurons against ethanol-induced damage: a biochemical, morphological and behavioral study. Neuroscience. 2007;146(4):1581-92.

[57] Hayakawa N, Kato H, Araki T. Age-related changes of astorocytes, oligodendrocytes and microglia in the mouse hippocampal CA1 sector. Mech Ageing Dev. 2007;128(4):311-6.

[58] Vlkolinsky R, Cairns N, Fountoulakis M, Lubec G. Decreased brain levels of 2',3'-cyclic nucleotide-3'-phosphodiesterase in Down syndrome and Alzheimer's disease. Neurobiol Aging. $2001 ; 22(4): 547-53$. 
[59] Muntoni F, Mateddu A, Serra G. Passive avoidance behaviour deficit in the mdx mouse. Neuromuscul Disord. 1991;1(2):121-3.

[60] Vaillend C, Ungerer A. Behavioral characterization of mdx3cv mice deficient in C-terminal dystrophins. Neuromuscul Disord. 1999;9(5):296-304.

[61] Vaillend C, Billard JM, Laroche S. Impaired long-term spatial and recognition memory and enhanced CA1 hippocampal LTP in the dystrophin-deficient $\mathrm{Dmd}(\mathrm{mdx})$ mouse. Neurobiol Dis. 2004;17(1):10-20.

[62] Anderson JL, Head SI, Rae C, Morley JW. Brain function in Duchenne muscular dystrophy. Brain. 2002;125(Pt 1):4-13.

[63] Priel A, Tuszynski JA, Woolf NJ. Neural cytoskeleton capabilities for learning and memory. J Biol Phys. 2009;36(1):3-21.

[64] Goda Y. Cadherins communicate structural plasticity of presynaptic and postsynaptic terminals. Neuron. 2002;35(1):1-3.

[65] Chan SL, Capdeville-Atkinson C, Atkinson J. Red wine polyphenols improve endotheliumdependent dilation in rat cerebral arterioles. J Cardiovasc Pharmacol. 2008;51(6):553-8.

[66] Dal-Ros S, Bronner C, Auger C, Schini-Kerth VB. Red wine polyphenols improve an established aging-related endothelial dysfunction in the mesenteric artery of middle-aged rats: role of oxidative stress. Biochem Biophys Res Commun. 2012;419(2):381-7.

[67] Radi R, Peluffo G, Alvarez MN, Naviliat M, Cayota A. Unraveling peroxynitrite formation in biological systems. Free Radical Biology and Medicine. 2001;30(5):463-88.

[68] Steffen Y, Schewe T, Sies H. (-)-Epicatechin elevates nitric oxide in endothelial cells via inhibition of NADPH oxidase. Biochemical and Biophysical Research Communications. 2007;359(3):828-33. [69] Schewe T, Steffen Y, Sies H. How do dietary flavanols improve vascular function? A position paper. Archives of Biochemistry and Biophysics. 2008;476(2):102-6.

[70] Vauzour D, Corona G, Spencer JP. Caffeic acid, tyrosol and p-coumaric acid are potent inhibitors of 5-S-cysteinyl-dopamine induced neurotoxicity. Arch Biochem Biophys. 2010;501(1):106-11. [71] Tsai SJ, Chao CY, Yin MC. Preventive and therapeutic effects of caffeic acid against inflammatory injury in striatum of MPTP-treated mice. Eur J Pharmacol. 2011;670(2-3):441-7. 
[72] Wei X, Ma Z, Fontanilla CV, Zhao L, Xu ZC, Taggliabraci V, Johnstone BH, Dodel RC, Farlow MR, Du Y. Caffeic acid phenethyl ester prevents cerebellar granule neurons (CGNs) against glutamate-induced neurotoxicity. Neuroscience. 2008;155(4):1098-105.

[73] Wei X, Zhao L, Ma Z, Holtzman DM, Yan C, Dodel RC, Hampel H, Oertel W, Farlow MR, Du Y. Caffeic acid phenethyl ester prevents neonatal hypoxic-ischaemic brain injury. Brain. 2004;127(Pt 12):2629-35.

[74] Youdim KA, Qaiser MZ, Begley DJ, Rice-Evans CA, Abbott NJ. Flavonoid permeability across an in situ model of the blood-brain barrier. Free Radical Biology and Medicine. 2004;36(5):592-604. [75] Meiergerd SM, Schenk JO. Striatal transporter for dopamine: catechol structure-activity studies and susceptibility to chemical modification. Journal of Neurochemistry. 1994;62(3):998-1008.

[76] Nardini M, Scaccini C, Packer L, Virgili F. In vitro inhibition of the activity of phosphorylase kinase, protein kinase $\mathrm{C}$ and protein kinase $\mathrm{A}$ by caffeic acid and a procyanidin-rich pine bark (Pinus marittima) extract. Biochimica et Biophysica Acta. 2000;1474(2):219-25.

[77] Kerry N, Rice-Evans C. Inhibition of peroxynitrite-mediated oxidation of dopamine by flavonoid and phenolic antioxidants and their structural relationships. Journal of Neurochemistry. 1999;73(1):247-53.

[78] Glisky EL. Changes in Cognitive Function in Human Aging. In: Riddle DR, editor. Brain Aging: Models, Methods, and Mechanisms. Frontiers in Neurosciences. 2011/01/05 ed. Boca Raton (FL): CRC Press; 2007.

[79] Joseph J, Cole G, Head E, Ingram D. Nutrition, brain aging, and neurodegeneration. J Neurosci. 2009;29(41):12795-801.

[80] Joseph JA, Shukitt-Hale B, Casadesus G. Reversing the deleterious effects of aging on neuronal communication and behavior: beneficial properties of fruit polyphenolic compounds. The American journal of clinical nutrition. 2005;81(1 Suppl):313S-6S.

[81] Williams CM, El Mohsen MA, Vauzour D, Rendeiro C, Butler LT, Ellis JA, Whiteman M, Spencer JP. Blueberry-induced changes in spatial working memory correlate with changes in hippocampal CREB phosphorylation and brain-derived neurotrophic factor (BDNF) levels. Free Radic Biol Med. 2008;45(3):295-305. 
[82] Rendeiro C, Spencer JP, Vauzour D, Butler LT, Ellis JA, Williams CM. The impact of flavonoids on spatial memory in rodents: from behaviour to underlying hippocampal mechanisms. Genes Nutr. 2009.

[83] Vauzour D, Minihane AM. Neuroinflammation and the APO $\varepsilon$ genotype: Implications for Alzheimer's disease and modulation by dietary flavonoids and n-3 polyunsaturated fatty acids. Nutrition and Aging. 2012;1(1):41-53.

[84] Lamport DJ, Dye L, Wightman JD, Lawton CL. The effects of flavonoid and other polyphenol consumption on cognitive performance: A systematic research review of human experimental and epidemiological studies. Nutrition and Aging. 2012;1(1):5-25.

[85] Willis LM, Shukitt-Hale B, Joseph JA. Modulation of cognition and behavior in aged animals: role for antioxidant- and essential fatty acid-rich plant foods. The American journal of clinical nutrition. 2009;89(5):1602S-6S.

[86] Spencer JP. The impact of fruit flavonoids on memory and cognition. Br J Nutr. 2010;104 Suppl 3:S40-7.

[87] Spencer JP, Vauzour D, Rendeiro C. Flavonoids and cognition: the molecular mechanisms underlying their behavioural effects. Arch Biochem Biophys. 2009;492(1-2):1-9.

[88] Joseph JA, Shukitt-Hale B, Denisova NA, Bielinski D, Martin A, McEwen JJ, Bickford PC.

Reversals of age-related declines in neuronal signal transduction, cognitive, and motor behavioral deficits with blueberry, spinach, or strawberry dietary supplementation. J Neurosci. 1999;19(18):811421.

[89] Ghosh D, Scheepens A. Vascular action of polyphenols. Mol Nutr Food Res. 2009;53(3):322-31.

[90] Casadesus G, Shukitt-Hale B, Stellwagen HM, Zhu X, Lee HG, Smith MA, Joseph JA. Modulation of hippocampal plasticity and cognitive behavior by short-term blueberry supplementation in aged rats. Nutr Neurosci. 2004;7(5-6):309-16.

[91] Mubarak A, Bondonno CP, Liu AH, Considine MJ, Rich L, Mas E, Croft KD, Hodgson J. Acute effects of chlorogenic acid on nitric oxide status, endothelial function and blood pressure in healthy volunteers: a randomised trial. J Agric Food Chem. 2012.

[92] Vauzour D, Rodriguez-Mateos A, Corona G, Oruna-Concha MJ, Spencer JP. Polyphenols and human health: prevention of disease and mechanisms of action. Nutrients. 2010;2(11):1106-31. 
Table 1. Phenolic compounds in Champagne wine

\begin{tabular}{cc}
\hline Phenolic compounds & $(\mathbf{m g} / \mathbf{L})$ \\
\hline gallic acid & 0.66 \\
protocatechuic acid & 0.50 \\
tyrosol & 8.46 \\
caftaric acid & 5.01 \\
caffeic acid & 1.43 \\
\hline total phenolics & 16.06 \\
\hline
\end{tabular}




\section{Figure legends}

Figure 1. Postulated effects of Champagne wine phenolics on the cardiovascular system

Figure 2. Postulated effects of Champagne wine phenolics on memory and cognition 


\section{List of Figures}

Figure 1.

Champagne wine phenolics

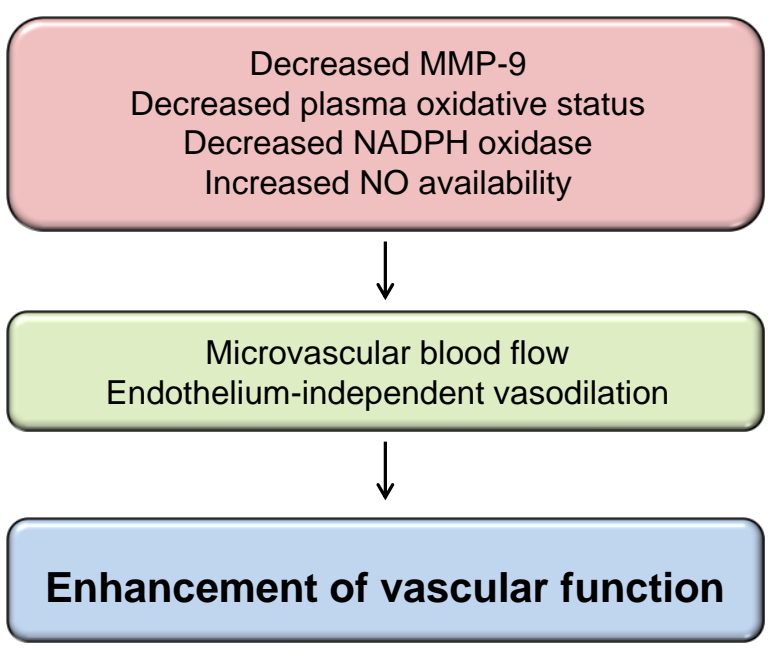


Figure 2.

Champagne wine phenolics

\begin{tabular}{|c|c|c|c|}
\hline $\begin{array}{c}\text { P38 / CREB / BDNF } \\
\text { Phosphotreonine } \\
\text { GAP-1 }\end{array}$ & $\begin{array}{l}\text { Dystrophin } \\
\text { CNPase } \\
\text { Plakoglobin }\end{array}$ & $\begin{array}{c}\text { Bcl-xL } \\
\text { Bcl-x } \\
\text { Caspase } 5 / 6 / 11\end{array}$ & $\begin{array}{l}\text { Cyclin A } \\
\text { cdc27 } \\
\text { c-myc }\end{array}$ \\
\hline$\downarrow$ & $\downarrow$ & $\downarrow$ & $\downarrow$ \\
\hline $\begin{array}{c}\text { Signal } \\
\text { transduction }\end{array}$ & $\begin{array}{l}\text { Neuronal } \\
\text { plasticity }\end{array}$ & Apoptosis & $\begin{array}{l}\text { Cell } \\
\text { cycle }\end{array}$ \\
\hline$\downarrow$ & $\downarrow$ & $\downarrow$ & $\downarrow$ \\
\hline \multicolumn{4}{|c|}{ ment of memory and cognition } \\
\hline
\end{tabular}

